\title{
Impact of risks and threats on the region's food supply in the context of import substitution
}

\author{
Svetlana M. Kurbatova ${ }^{1, *}$, Valery V. Vlasov ${ }^{2,3}$, and Larisa Yu. Aisner ${ }^{4}$ \\ ${ }^{1}$ Peter the Great Sankt-Petersburg Polytechnic university \\ ${ }^{2}$ Hamburg University of Technology (TUHH) \\ ${ }^{3}$ Saratov State Medical University \\ ${ }^{4}$ Krasnoyarsk State Agrarian University
}

\begin{abstract}
The introduction against Russia of "food sanctions" promoted the interest of scientists to analyze such scientific categories as "risks" and "threats" in the agricultural sector of the economy in terms of import substitution. Largely, the introduction of food sanctions is intended to reorient Russia's foreign trade markets in order to find suppliers that are free from the current political environment. Reducing competition should help domestic agricultural producers to work effectively and reach a leading position in their food segment. The importance to study the emerging risks and threats in relation to the regional food supply system in the process of import substitution is connected with the fact that without proper understanding and analysis, a significant number of problems of economic, social and managerial relations in the food turnover both within the state and within the borders of a separate region can arise. In the article, the authors attempt to show the risks and threats of food security in the region in modern economic conditions.
\end{abstract}

\section{Introduction}

One of the strategic objectives of the Russian system of economic security, according to the authors, is to ensure the security of the real sector of the economy, which, without any doubt, should include the food segment. The purpose of this study is to show the impact of individual risks and threats that affect the development of the region's food supply system based on systematic and integrated approaches. Food security and increasing the competitiveness of domestic food in the domestic and foreign markets, because of our country's joining the WTO, are strategic goals of the agricultural policy of Russian [1].

At present, import substitution of food products is extremely important. These issues are among the priority tasks at both the Federal and regional levels. Effective provision of safe and high-quality food products to the population of the country is one of the most important socio-economic tasks. They should be solved not only at the level of federal government, but also at the regional level as well. One of the authors of this study drew attention to the fact that: "an objective understanding of the specificity and values of a social phenomenon, in our case, food security should be initially substantiated and analysed on the basis of the historical experience of the phenomenon under study" [2].

The vector of progressive development of productive forces in the Siberian Federal district (SFD) depends on the effective solution of economic problems in the Krasnoyarsk territory; development of agriculture deserves special attention. The Krasnoyarsk territory belongs to the main regions of Russia. Moreover, it is one of the leaders among all subjects of the Russian Federation in terms of such important macroeconomic indicators as population, gross regional product (GRP), industrial production, construction work, investment in fixed assets and their contribution to the overall development indicators of the country [3].

Krasnoyarsk territory is one of the largest economic regions of the Russian Federation, the second largest in the country. Industrial development of the region is determined by metallurgical, construction, fuel and energy, forest, agricultural and industrial complexes. The region differs from others in terms of its considerable diversity and richness of natural conditions and resources. Geographically, it occupies a strategic position, since it is located in Eastern Siberia, almost in the heart of the Eurasian continent. It should be noted that the territory of the region can act as one of the strategic factors of its socio-economic development. In the North of Krasnoyarsk territory, its mainland is bounded by the Kara sea and the Laptev sea. In the South, the border is the mountains of the Eastern and Western Sayans, the Abakan range, and the Kuznetsk Alatau. In the West, the border of Krasnoyarsk territory runs along the watershed of the $\mathrm{Ob}$ and Yenissei rivers, and in the East-along the Middle Siberian plateau, where the lower and Podkamennaya Tunguska rivers directly converge in their upper reaches. The politicaladministrative border of the region to the West adjacent to Tyumen, Tomsk and Kemerovo regions and the Altai territory; in the East the Krasnoyarsk territory borders

\footnotetext{
* Corresponding author: sveta_kurbatova@mail.ru
} 
the Republic of Sakha (Yakutia) and Irkutsk region and in the South - the Republics of Tyva and Khakassia.

Krasnoyarsk territory occupies 2366.8 thousand $\mathrm{km}^{2}$. The share in the total territory of Russia is $13,86 \%$. [4] The length of the region is from North to South - about $3000 \mathrm{~km}$, from West to East - $1250 \mathrm{~km}$. In Siberia and the Far East in terms of population, the region is the largest subject of the Russian Federation. As of January $1,2018,2876.5$ thousand people lived in the region. They account for about $15 \%$ of the population of the Siberian Federal district and $2 \%$ of the country's population. The population density is 1.2 people per 1 $\mathrm{km} 2$. 2226.1 thousand people live in cities (including three cities with a population of 100 thousand or more people: Krasnoyarsk - 1091.6 thousand, Norilsk - 179.6 thousand, Achinsk - 105.3 thousand); 650.4 thousand people live in rural areas. The percentage of the urban population in the region is $77.4 \%$; that of the rural population is $22.6 \%$. (According to the Office of the Federal service for state registration, cadastre and cartography for the Krasnoyarsk territory as of January 1, 2018) [4].

\section{Risks of food security in the region}

The food security doctrine of the Russian Federation approved by the presidential decree No. 120 dated January 30, 2010 states that food security is one of the main directions of ensuring the country's national security in the medium term, a factor in preserving its statehood and sovereignty, and an important component of demographic policy. All regions of the Russian Federation are more or less differentiated in terms of self-sufficiency in food due to differences in the bioclimatic and production potential of agriculture. Food security is one of the main directions of national security of the Russian Federation. Its achievement, in accordance with the decree of the President of the Russian Federation dated December, 31st, 2015 № 683 "On the national security Strategy of the Russian Federation" (hereinafter - the national security Strategy), is essential to improving the quality of life of citizens of the Russian Federation [5].

It is necessary to seriously change the priorities in the agricultural policy of the subjects of the Russian Federation. It is necessary to increase the effectiveness of state support, which should create conditions for structural changes in agricultural production and form a system of state information support [6]. It is necessary to pay more attention to the development of the processing industry, identify and develop effective business models, create a credit system that is profitable for the village, create large logistics food centers in cities that would allow the sale of agricultural products. The complex development of rural areas that would be attractive for young specialists to agricultural production and developing the system of agricultural education are necessary [7]. Various risks affect the food supply of any region [8], among the most significant of them are the following: macroeconomic risks, agroecological risks, financial risks, management risks, criminal risks, foreign economic risks associated with the introduction of economic sanctions against Russia.

\section{Threats to food security in the region}

The national security strategy, defines threat as a combination of factors and conditions that create an indirect or direct possibility of harming the country's national interests. Food security threats can be defined as a subsystem of threats to a country's national security. Threats to food security in the region can be considered as the processes and phenomena of economic, social and legal nature, which causes instability of agricultural production, its established structures, strengthening of territorial fragmentation and general deterioration of life of the rural population. The national security strategy groups them into four main categories. The first is based on the identification of threats to increase the property differentiation of the population and increase the level of poverty, leading to the violation of social peace and social harmony. The second - reflects the threats resulting from the deformed structure of the Russian economy. The third - focuses on the increasing inequality of socio-economic development of regions. And the fourth-on the criminalization of society and economic activity. As noted in the concept of national security, these economic threats are complex. They accumulate negative trends: a significant reduction in GDP; reduced investment to innovative activity of scientific and technical potential; stagnation of the agricultural sector; the imbalance of the banking system; the rise in external and internal public debt; the predominance in export supplies of fuel and raw materials and energy components; dependence on import in food and consumer goods, including basic necessities [9].

It is well known that classification is the process of dividing the entire set of research objects into several classes, depending on the selected criterion. It is always conditional in nature, but as J. S. Mill rightly pointed out, it is classification that makes ideas about objects accompany one another, gives power over already acquired knowledge and leads to the acquisition of new knowledge [10]. In table 1. the author's classification of certain types of threats to food security in the region is given. 
Table 1. Classification of certain types of threats to food security in the region.

\begin{tabular}{|c|c|c|}
\hline & Classification criterion & $\begin{array}{l}\text { Types of threats to } \\
\text { food security in the } \\
\text { region }\end{array}$ \\
\hline 1 & according to the source & external and internal \\
\hline 2 & at the time of occurrence & real and potential \\
\hline 3 & in some areas & $\begin{array}{lr}\text { banking, } & \text { insurance, } \\
\text { tax, } & \text { financial, } \\
\text { business, } & \text { currency } \\
\text { and others } & \\
\end{array}$ \\
\hline 4 & by area of origin & $\begin{array}{l}\text { economic, political, } \\
\text { social, } \\
\text { environmental, } \\
\text { military, } \\
\text { demographic, legal } \\
\text { and other }\end{array}$ \\
\hline 5 & $\begin{array}{ll}\text { possible } & \text { negative } \\
\text { consequences } & \end{array}$ & $\begin{array}{l}\text { global, national, sub- } \\
\text { regional, regional, } \\
\text { municipal, local }\end{array}$ \\
\hline 6 & $\begin{array}{l}\text { the impact on the control } \\
\text { object }\end{array}$ & active and passive \\
\hline 7 & $\begin{array}{l}\text { according to the degree } \\
\text { of evidence }\end{array}$ & explicit and hidden \\
\hline 8 & by frequency of threats & $\begin{array}{l}\text { permanent and } \\
\text { random }\end{array}$ \\
\hline 9 & $\begin{array}{l}\text { by volume of distribution } \\
\text { in the territory }\end{array}$ & $\begin{array}{l}\text { full (entire region) } \\
\text { and partial (on the } \\
\text { territory of one or } \\
\text { more municipalities) }\end{array}$ \\
\hline 10 & if possible, forecast & $\begin{array}{ll}\text { predicted and } \\
\text { unpredictable }\end{array}$ \\
\hline 11 & by degree of influence & $\begin{array}{l}\text { absolute, relative, } \\
\text { threshold }\end{array}$ \\
\hline 12 & $\begin{array}{l}\text { by the amount of alleged } \\
\text { damage }\end{array}$ & $\begin{array}{l}\text { minor, significant, } \\
\text { catastrophic }\end{array}$ \\
\hline 13 & at the time of action & past, present, future \\
\hline
\end{tabular}

S. Y. Glazyev considers the main internal threats to food security as following:

- low real incomes of the general population and its high level of debt load;

- the reduction in the number of small farms, concentration of production within individual enterprises and corporations;

- changing patterns of consumption and quality requirements of food products;

- deepening of stratification of society;

- the low competitiveness of agriculture, food industry;

- low level of development of industries that provide agriculture with material and technical resources (services);

- market openness and the predominance of imported products;

- underdevelopment of the food market infrastructure, rising unemployment, deterioration of the social situation in rural areas;

- dependence of the agro-food market on the energy market; incomplete land reform (in some republics), which creates conditions for mass shadow turnover of land;

- transition of large land holdings under the control of foreigners [11].
I. A. Sergeeva, A. Yu. Sergeev in relation to the main external threats to food security (but not to food supply), distinguish: the state of foreign economic relations, economic sanctions by a number of countries; increasing risks of instability of the world economy; low competitiveness of domestic agricultural products; changes in the national currency; dynamics of world food prices; reduction in the level of world food supplies; increase in energy prices; restrictions on trade in food products on the world agro-food market [12].

Real and potential threats are of particular importance not only in theory, but also in the practice of managing the region's food supply. In particular, food sanctions against Russia by the EU, the United States and some other countries are real threats. If other countries join the UE and the USA they can be attributed to potential threats. In some areas, we can distinguish: banking, insurance, tax, financial, business, currency and other threats. It is not possible to make an exhaustive list of threats in the sphere of their occurrence, but the most important ones, according to the author's subjective opinion, are such as: economic, political, social, environmental, military, demographic, legal, and other. Possible negative consequences: global, national, subregional, regional, municipal, local.

According to the impact on management, food security threats can be classified into: active and passive. According to the degree of evidence, it is necessary to indicate: obvious and hidden threats. If we take such a criterion as the frequency of threats, we can talk about permanent and random types of threats. It is also possible to distinguish the types of threats to food security by the volume of distribution on the territory of the region: complete (the entire region) and partial (on the territory of one or more municipalities). According to such criteria as the ability to predict threats: they can be either predicted or not predicted. We believe that it is also appropriate to classify threats by the degree of influence, based on this criterion, they will be: absolute, relative, and threshold. Another possible classification of threats to the food supply of the region can be carried out by the magnitude of the alleged damage. In accordance with the above criteria, threats can be: minor, significant, or catastrophic. In accordance with the above-mentioned feature (time of action), all existing threats can be grouped in relation to the region into: past, present, and future [13].

\section{Conclusions}

In conclusion, it should be noted that at present, the patterns of formation, functioning, and impact of risks and threats on regional food markets are poorly understood and require further scientific research. We are convinced that in order to achieve proper interaction and effective coordination of the activities of state authorities in the region (in our case, the Krasnoyarsk territory) and agricultural producers and in order to implement high-quality agricultural regional policy in the Krasnoyarsk territory, it is advisable to establish a special expert Advisory body - the food security Council 
of the Krasnoyarsk territory [14]. The use of an effective management system, which should be based on the interaction of public authorities and civil society, will help prevent the risks and threats of food security in the region, as well as improve the socio-economic situation in the Krasnoyarsk territory. In connection with the foregoing, it is advisable to draft and adopt the Law of Krasnoyarsk region "About food safety of Krasnoyarsk region".

\section{References}

[1] S.M.Trashkova, L.Yu. Aisner, Some regulatory and legal aspects of the development of staffing for the rural economy as part of state policy at the present stage, Agrarian and land law, 4, 148, 2628.

[2] V.A. Vlasov, Historical-legal aspect of the Genesis of formation and development of food security at the global level, History of state and law, 1, 59-65 (2020).

[3] V.A. Vlasov, Peculiarities of natural and economic conditions influencing food security of the region population, In the collection: IOP Conference Series: Earth and Environmental Science Krasnodar Science and Technology City Hall of the Russian Union of Scientific and Engineering Associations, 22074 (2019).

[4] Krasnoyarsk territory in figures 2017: Stat.sat., Krasnoyarsk state Statistics service, Krasnoyarsk, 9, 18 (2018).

[5] The national security Strategy of the Russian Federation. Approved by presidential decree, no. 683 dated 31.12.2015, Consultant plus (2015).

[6] S.M. Kurbatova, L.Yu. Aisner, Legal foundations of state social security in the field of agriculture, Agrarian and land law, 6, 162, 139-142 (2018).

[7] S.M. Kurbatova, L.Yu. Aisner, Agricultural education, Colloquium-journal, 9-6, 33, 39-41 (2019).

[8] L.V. Shulgina, O.I. Yudin, O.Yu. Savenkova, Fundamentals of risk management in the activities of agricultural machinery enterprises, FES: Finance, Economy, 8, 23-27 (2013).

[9] A.O. Varyukha, L.V. Surzhenko, Modern threats to Russia's economic security, Young scientist, 8 , 3-5 (2016).

[10] S.V. Meyen, Yu. A. Schreider, Methodological aspects of the classification theory, Questions of philosophy, 12, 67-79 (1976).

[11] S.Yu. Glazyev, On food security in Russia, Izborsky club: Information portal [Electronic resource]. Available at: http://www.dynacon.ru/content/article.

[12] I.A. Sergeeva, A.Yu. Sergeev, Threats to food security in Russia, Foodpolicy and security, 1, 1, 1324 (2014).

[13] V.A. Vlasov, Questions of classification of threats that affect the development of the region's food supply system, FES: Finance, Economy, 16, 2, 50-55 (2019).
[14] V.A. Vlasov, Improving the legislation of the Krasnoyarsk territory on ensuring food security in terms of import substitution: current problems and prospects, State power and local self-government, 10, 45-49 (2018). 